\title{
ANALISIS PENYEBAB KEGAGALAN MENDIRIKAN USAHA BARU PADA PARA LULUSAN PROGRAM WIRAUSAHA BARU JAWA BARAT KELAS IDE BISNIS
}

\author{
Rida Srihadiastuti, Universitas Telkom \\ rsrihadiastuti@gmail.com \\ Deden Syarif Hidayatullah, Universitas Telkom \\ dedensy@telkomuniversity.ac.id
}

\begin{abstract}
ABSTRAK
Program Wirausaha Baru Jawa Barat (WUB Jabar) yang diselenggarakan oleh Badiklatkop kota Bandung, merupakan pelatihan kewirausahaan pada 3 pilihan bidang usaha, yakni makanan-minuman, konveksi, dan salon. Peserta dibagi ke dalam kelas Ide Bisnis, kelas Start-up (usaha pemula), atau kelas Growth (pengembangan). Kelas Ide Bisnis diperuntukkan bagi peserta yang belum mempunyai usaha, atau sudah mempunyai usaha namun belum mencapai usia 1 tahun. Melalui survei terhadap 237 para lulusan kelas Ide Bisnis, tercatat sebanyak 21 orang mengalami kegagalan mendirikan usaha baru pasca mengikuti program ini. Penelitian ini bertujuan untuk mengetahui faktor-faktor penyebab kegagalan tersebut. Metode kualitatif deskriptif digunakan dalam penelitian ini. Teknik pengumpulan data dengan observasi program WUB Jabar, dan wawancara kepada 7 lulusan yang mengalami kegagalan usaha, juga kepada 5 lulusan yang usahanya masih berlanjut. Teknik analisis data dengan model Miles dan Huberman. Hasil penelitian ini memaparkan bahwa faktor utama penyebab kegagalan usaha baru para lulusan adalah kendala pada permodalan, karena kendala pada permodalan menyebabkan kendalakendala pada faktor lainnya. Dan faktor permodalan juga menjadi kendala yang paling sulit diatasi para lulusan yang tidak mengalami kegagalan usaha.
\end{abstract}

Kata Kunci: Lingkungan Keluarga, Kedisiplinan

\begin{abstract}
Wirausaha Baru Jawa Barat Program (WUB Jabar Program) which organized by Badiklatkop Bandung, is an entrepreneurship training in 3 choices of business field, those are food-beverage, convection, and salon. Participants are divided into Ide Bisnis class, Start-up class, or Growth class. Ide Bisnis Class is for participants who do not have business, or already have business but not yet reached the age of 1 year. Through a survey of 237 Ide Bisnis class graduates, there were 21 people who failed in establishing their new business after participated in the program. This research aims to determine the factors that causing failure. Qualitative descriptive method used in this research. Data collection techniques with observation of program WUB Jabar, and interviews to 7 graduates who
\end{abstract}


experienced business failure, also to 5 graduates whose business is still continuing. Data analysis techniques with Miles and Huberman models. The results of this research explained that the main factor causing graduates's new business failure is the barrier on capital, because barriers on capital causing barriers on other factors. And capital factor is also the most difficult barrier to be solved by the graduates who do not experience business failure.

Keywords: Business Failure, Entrepreneurship Training, New Business.

\section{PENDAHULUAN}

Mendapatkan pendidikan kewirausahaan adalah hak rakyat Indonesia untuk mengembangkan potensi diri. Pemerintah berkewajiban mengembangkan sumber daya manusia seperti yang diatur dalam Pasal 19 huruf c Undang-Undang No.20 Tahun 2008 tentang Usaha Mikro, Kecil, dan Menengah. Pasal tersebut berbunyi "Pengembangan dalam bidang sumber manusia sebagaimana dimaksud dalam Pasal 16 ayat (1) huruf c dilakukan dengan cara: ....... c. membentuk dan mengembangkan lembaga pendidikan, pelatihan, penyuluhan motivasi dan kreativitas bisnis, dan penciptaan wirausaha baru".

Salah satu upaya pemerintah Indonesia dan pemerintah Provinsi Jawa Barat dalam mewujudkan hak tersebut adalah dengan menciptakan program pelatihan kewirausahaan yaitu Program Wirausaha Baru Jawa Barat (WUB Jabar). Program ini dilaksanakan oleh 13 OPD (Officer Development Program), salah satunya adalah Balai Pendidikan dan Pelatihan Koperasi dan Wirausaha (Badiklatkop) Kota Bandung. Target dari program ini adalah menciptakan 100.000 wirausaha baru di Provinsi Jawa Barat.

Program WUB Jabar yang diselenggarakan oleh Badiklatkop di kota Bandung diperuntukkan bagi masyarakat pemilik KTP Provinsi Jawa Barat yang tersebar di seluruh 27 kabupaten/kota. Program ini terdiri dari 4 tahap, yakni: 1) Pendaftaran online atau onsite; 2) Seleksi, wawancara mengenai proposal usaha yang diajukan saat pendaftaran; 3) Pelatihan selama 4 hari (3 hari teori, 1 hari praktik magang); dan 4) Pendampingan usaha di kediaman para peserta.

Pelatihan kewirausahaan program ini menawarkan 3 pilihan bidang usaha : 1) Konveksi, 2) Salon, dan 3) Makanan-minuman. Peserta dibagi ke dalam kelas berdasarkan 3 kriteria lama usaha: 1) kelas Ide Bisnis (usaha 0 tahun); 2) kelas Start-up/usaha pemula (usaha 1-2 tahun); dan 3) kelas Growth/pengembangan (usaha 3-5 tahun). Kelas Ide Bisnis diperuntukkan bagi para peserta yang belum berwirausaha atau sudah memiliki usaha namun belum mencapai usia 1 tahun. Sedangkan 2 kelas lainnya diperuntukkan bagi peserta yang sudah memiliki usaha melebihi usia 1 tahun.

Penelitian ini hanya akan meneliti para lulusan program WUB Jabar binaan Badiklatop kelas Ide Bisnis. Badiklatkop sendiri sudah mencetak 5.300 lulusan dari tahun 2014 hingga tahun 2017, dengan 2.228 orang diantaranya termasuk ke dalam kelas Ide Bisnis. Para peserta kelas Ide Bisnis pada umumnya adalah orang-orang yang baru akan mendirikan usaha baru. Dan usaha yang akan didirikan pada umumnya adalah usaha mikro atau usaha kecil. 
Kriteria Usaha Mikro berdasarkan Undang-Undang No.20 Tahun 2008 adalah usaha dengan kekayaan bersih paling banyak Rp50.000.000,00 (lima puluh juta rupiah) tidak termasuk tanah dan bangunan tempat usaha, dan memiliki hasil penjualan tahunan paling banyak Rp300.000.000,00 (tiga ratus juta rupiah). Sedangkan Usaha Kecil adalah usaha dengan kekayaan mulai dari Rp50.000.000,00 (lima puluh juta rupiah) hingga paling banyak Rp500.000.000,00 (lima ratus juta rupiah) tidak termasuk tanah dan bangunan tempat usaha, dan memiliki hasil penjualan tahunan mulai dari Rp300.000.000,00 (tiga ratus juta rupiah) hingga paling banyak Rp2.500.000.000,00 (dua milyar lima ratus juta rupiah).

Menurut Suryana (2008) "merintis usaha baru, yaitu membentuk dan mendirikan usaha baru dengan menggunakan modal, ide, organisasi dan manajemen yang dirancang sendiri. Ada 3 bentuk usaha baru yang dapat dirintis: 1) Perusahaan milik sendiri (sole proprietorship), yakni bentuk usaha yang dimiliki dan dikelola sendiri oleh seseorang; 2) Persekutuan (partnership), yakni kerja sama (asosiasi) antara dua orang atau lebih; dan 3) Perusahaan berbadan hukum (corporation), yakni perusahaan yang didirikan atas dasar badan hukum dengan modal berupa saham."

Pasca mengikuti program WUB Jabar, tidak semua lulusan berhasil mendirikan usaha baru. Berdasarkan hasil survei pada tanggal 21-31 Desember 2017 pada para lulusan Program WUB Jabar kelas Ide Bisnis. Sebanyak 43 lulusan masih pada tahap perencanaan usaha, sebanyak 155 lulusan sedang atau masih berwirausaha, sebanyak 21 orang mengalami kegagalan berwirausaha atau terhenti dalam mendirikan usaha baru, dan 18 orang menyatakan tidak berupaya berwirausaha pasca mengikuti pelatihan dan pendampingan program WUB Jabar.

Penyelenggara program WUB Jabar menyatakan beberapa asumsi penyebab para lulusan WUB Jabar mengalami kegagalan dalam mendirikan usaha barunya, namun belum pernah melakukan penelitian secara khusus terhadap fenomena kegagalan tersebut. Ibu Hetty Susilawaty, S.E, M.M selaku Ketua Seksi Pelaksana Pelatihan Program WUB Jabar (Badiklatkop) beranggapan penyebab kegagalan usaha baru para lulusan dikarenakan kendala permodalan. Sedangkan ibu Siti Nur Maftuhah, SP, MPt selaku Koordinator Pendamping beranggapan penyebab kegagalan usaha baru para lulusan adalah karena 4 hal, yaitu 1) motivasi berwirausaha lemah, 2) pengetahuan terbatas, 3) rencana bisnis tidak matang, dan 4) modal yang terbatas.

Tabel 1. Rekapitulasi Jumlah Lulusan Kelas Ide Bisnis Berdasarkan Kondisi Usaha

\begin{tabular}{ccccc}
\hline & \multicolumn{2}{c}{ Mengalami Kegagalan Usaha } & \multicolumn{2}{c}{ Masih Berwirausaha } \\
Bidang Usaha & Sebelum & Setelah & Belum & Sudah \\
(Pelatihan) & mencapai & mencapai & mencapai 1 & mencapai 1 \\
& 1 tahun & 1 tahun & tahun & tahun \\
\hline Makanan-Minuman & 10 orang & 6 orang & 38 orang & 52 orang \\
Konveksi & 3 orang & 1 orang & 16 orang & 23 orang \\
Salon & 1 orang & - & 10 orang & 16 orang \\
& 14 orang & 7 orang & 64 orang & 91 orang \\
Total & \multicolumn{2}{c}{21 orang } & \multicolumn{2}{c}{155 orang } \\
\hline
\end{tabular}


Melalui survei awal, didapatkan data mengenai lulusan kelas Ide Bisnis yang mengalami kegagalan mendirikan usaha baru maupun yang masih berwirausaha adalah seperti pada tabel 1 . Demi mendapatkan informasi yang representatif dan mendalam, tidak dapat suatu kasus kegagalan usaha baru disamakan dengan kasus lainnya. Oleh karena itu penelitian ini merumusakan masalah sebagai berikut:

1) Menganalisa faktor-faktor penyebab kegagalan usaha baru para lulusan kelas Ide Bisnis dari beberapa kasus yang berbeda jenis usaha.

2) Menganalisa kendala yang paling sulit diatasi usaha baru para lulusan yang masih berlanjut (tidak mengalami kegagalan).

3) Dari kedua temuan tersebut akan dianalisis apa saja kendala yang paling sering ditemui, dan bagaimana cara para lulusan mengatasinya.

Tujuan dari penelitian ini adalah dapat merefleksikan kondisi sebenarnya dari fenomena yang ada, dapat menghasilkan sebuah temuan berharga yang menjadi landasan perbaikan program Wirausaha Baru Jawa Barat itu sendiri.

Berbagai bentuk kegagalan usaha menurut Astamoen (2008) diantaranya tidak tercapainya tujuan seperti yang direncanakan semula, kalah, rugi, bangkrut, batal, tertipu, terperdaya, terkecoh, celaka, ditolak, disisihkan, diabaikan, tidak lulus, dan tidak ada kemajuan.

Menurut Suparyanto (2012) Kelemahan yang paling pokok yang dialami oleh sebagian besar usaha kecil adalah pada aspek manajemen, dapat diklasifikasikan sebagai berikut: 1) Kelemahan Aspek Manajemen Pemasaran; 2) Kelemahan Aspek Manajemen Operasi; 3) Kelemahan Aspek Manajemen Sumber Daya Manusia; dan 4) Kelemahan Aspek Manajemen Keuangan.

Menurut Machfoedz (2015) wirausahawan yang menemui kegagalan jauh lebih banyak daripada mereka yang berhasil, ada beberapa alasan penyebab kegagalan yang perlu diperhatikan, diantaranya: 1) Pengalaman manajemen; 2) Perencanaan keuangan; 3) Analisis lokasi; 4) Bersifat boros; dan 5) Kebersediaan untuk Berkorban.

Menurut Zimmerer dan Scarborough (2008) mengemukakan sepuluh kesalahan fatal yang menyebabkan kegagalan usaha kecil, diantaranya: 1) ketidakmampuan manajemen; 2) kurang pengalaman; 3) pengendalian keuangan yang buruk; 4) lemahnya usaha pemasaran; 5) kegagalan mengembangkan perencanaan strategis; 6) pertumbuhan yang tak terkendali; 7) lokasi yang buruk; 8) pengendalian persediaan yang tidak tepat; 9) penetapan harga yang tidak tepat; dan 10) ketidakmampuan membuat transisi kewirausahaan.

\section{METODE PENELITIAN}

Metode yang digunakan pada penelitian ini adalah kualitatif deskriptif, dengan maksud mendeskripsikan hasil penelitian dari objek yang diteliti, yakni usaha baru para lulusan program WUB Jabar kelas Ide Bisnis yang mengalami kegagalan maupun tidak mengalami kegagalan. Metode ini juga mampu mengeksplorasi objek penelitian dengan serangkaian prosedur wawancara dengan pihak-pihak yang terkait. 
Ditetapkan 16 variabel operasional pada penelitian ini, diantaranya: 1) Motivasi berwirausaha; 2) Pengalaman berwirausaha; 3.) Pengetahuan berwirausaha; 4) Perencanaan usaha; 5) Analisis kelayakan usaha; 6) Kepemilikan usaha; 7) Permodalan; 8) Manajemen SDM; 9) Manajemen operasi; 10) Manajemen pemasaran; 11) Manajemen keuangan; 12) Pesaing; 13) Hubungan dengan pelanggan; 14) Hubungan dengan pemasok; 15) Transisi usaha; dan 16) Perekonomian.

Variabel-variabel operasional penelitian tersebut ditetapkan berdasarkan teori-teori yang dipakai, diantaranya teori mengenai motivasi berwirausaha menurut Alma (2014), teori mengenai penyebab kegagalan usaha kecil menurut Zimmerer dan Scarborough (2008), teori mengenai perencanaan usaha menurut Zimmerer dan Scarborough (2008), teori mengenai kepemilikan usaha menurut Zimmerer dan Scarborough (2008), teori mengenai analisis kelayakan usaha menurut Suryana (2008), teori mengenai faktor-faktor penyebab kegagalan usaha dan penyebab kegagalan usahawan pemula menurut Machfoedz (2015), teori mengenai kelemahan usaha kecil menurut Suparyanto (2012), teori mengenai masalah permodalan dalam proses pendirian usaha menurut Hisrich et. al. (2008).

Tabel 2. Variabel Operasional Penelitian

\begin{tabular}{|c|c|c|}
\hline Variabel & Konseptual & Operasional \\
\hline $\begin{array}{l}\text { Motivasi } \\
\text { Berwirausaha }\end{array}$ & $\begin{array}{l}\text { Tujuan dari para pemilik usaha kecil ialah } \\
\text { "achievement oriented" sedangkan para } \\
\text { manajer di perusahaan besar berorientasi pada } \\
\text { power dan prestige. Yang mana diantara } \\
\text { kedua orientasi ini akan berhasil, sangat } \\
\text { tergantung pada pengetahuan, keterampilan, } \\
\text { dan kepribadian individu dalam bisnisnya. } \\
\text { (Alma, 2014) }\end{array}$ & $\begin{array}{l}\text { kebebasan dalam berprestasi } \\
\text { memperoleh tambahan income } \\
\text { membantu famili } \\
\text { menyediakan komoditi }\end{array}$ \\
\hline $\begin{array}{l}\text { Pengalaman } \\
\text { Berwirausaha }\end{array}$ & $\begin{array}{l}\text { Menurut Zimmerer dan Scarborough (2008) } \\
\text { karena keterbatasan sumber daya, kurang } \\
\text { pengalaman manajemen, dan kurang stabilnya } \\
\text { keuangan, tingkat kematian bisnis kecil jauh } \\
\text { lebih tinggi dibandingkan bisnis yang lebih } \\
\text { besar dan mapan. }\end{array}$ & $\begin{array}{l}\text { Tidak pengalaman di } \\
\text { bidangnya } \\
\text { Kurang berpengalaman } \\
\text { berwirausaha } \\
\text { Kurang pengalaman } \\
\text { manajemen }\end{array}$ \\
\hline $\begin{array}{l}\text { Pengetahuan } \\
\text { Berwirausaha }\end{array}$ & $\begin{array}{l}\text { Zimmerer dan Scarborough (2008) } \\
\text { mengemukakan sepuluh kesalahan fatal yang } \\
\text { menyebabkan kegagalan bisnis, salah satu } \\
\text { diantaranya: Pemiliknya kurang mempunyai } \\
\text { kemampuan kepemimpinan, pertimbangan } \\
\text { yang baik, dan pengetahuan yang diperlukan } \\
\text { dalam menjalankan bisnis. }\end{array}$ & $\begin{array}{l}\text { Pengetahuan yang diperlukan } \\
\text { untuk menjalankan bisnis }\end{array}$ \\
\hline $\begin{array}{l}\text { Perencanaan } \\
\text { Usaha }\end{array}$ & $\begin{array}{l}\text { Terlalu banyak manajer perusahaan kecil } \\
\text { mengabaikan proses perencanaan strategis, } \\
\text { karena mereka mengira hal tersebut hanya } \\
\text { bermanfaat bagi perusahaan besar. Tanpa } \\
\text { strategi yang ditentukan dengan jelas, } \\
\text { perusahaan tidak memiliki dasar yang } \\
\text { berkesinambungan untuk menciptakan dan } \\
\text { memelihara keunggulan bersaing di pasar. } \\
\text { (Zimmerer dan Scarborough, 2008) }\end{array}$ & $\begin{array}{l}\text { Tidak melakukan perencanaan } \\
\text { tertulis } \\
\text { Semua aktivitas direncanakan } \\
\text { Perenanaan keuangan }\end{array}$ \\
\hline $\begin{array}{l}\text { Analisis } \\
\text { Kelayakan }\end{array}$ & $\begin{array}{l}\text { Hasil studi kelayakan usaha pada prinsipnya } \\
\text { bisa digunakan untuk } 3 \text { hal yakni untuk }\end{array}$ & $\begin{array}{l}\text { Aspek pasar } \\
\text { Aspek teknik produksi/operasi. }\end{array}$ \\
\hline
\end{tabular}


Usaha

merintis usaha baru, mengembangkan usaha yang sudah ada, dan memilih jenis usaha atau investasi/proyek yang paling menguntungkan. (Suryana, 2008)

Menurut Zimmerer dan Scarborough. (2008) dan paling populer masih tetap perusahaan perseorangan (sole proprietorship). Bentuk kepemilikan Persekutuan menurut Zimmerer dan Scarborough (2008) adalah kerja sama antara dua oranag atau lebih yang bersamasama memiliki perusahaan dengan tujuan menghasilkan laba.

\section{Kepemilikan} Usaha

Menurut Hisrich et. al. (2008) salah satu masalah tersulit dalam proses pendirian usaha baru adalah mendapatkan modal. bentuk kepemilikan yang paling sederhana

Aspek manajemen/pengelolaan

Aspek finansial/keuangan

Bentuk kepemilikan usaha

Kepemilikan perorangan

Kepemilikan persekutuan

Berbadan hokum

Perjanjian Persekutuan

Kelemahan Persekutuan

Sumber modal

Investor

Modal pinjaman

Modal pribadi

Kekurangan modal

Tidak bisa mengelola modal besar

Tidak adanya modal usaha

Menegur karyawan

Dominasi keluarga

Tugas dilakukan sendiri

Tidak dapat menerima umpan balik

Menurut Suparyanto (2012) Kelemahan yang paling pokok yang dialami oleh sebagian besar usaha kecil adalah pada aspek manajemen. Beberapa kelemahan umum yang sering terjadi pada aspek manajemen dapat diklasifikasikan sebagai berikut.

1. Kelemahan Aspek Manajemen Pemasaran

2. Kelemahan Aspek Manajemen Operasi

3. Kelemahan Aspek Manajemen SDM

4. Kelemahan Aspek Manajemen Keuangan

\section{Manajemen \\ Keuangan}

Banyak alasan yang dikemukakan oleh para usahawan pemula sehubungan dengan kegagalan mereka, seperti terlalu banyaknya pesaing, .......... (Machfoedz, 2015)

Lemahnya pemasaran menurut Zimmerer dan Scarborough (2008) Membangun basis pelanggan yang terus yang berkembang memerlukan usaha pemasaran tanpa kenal lelah dan kreatif. Mempertahankan mereka agar terus kembali diperlukan usaha, yaitu dengan menyediakan nilai, kualitas,
Teknologi sederhana

Skala produksi rendah

Biaya produksi tinggi

Terbatasnya pasar

Lemahnya riset pemasaran

Menjual secara kredit

Pemisahan dengan harta

pribadi

Pencatatan buruk

Piutang tidak tertagih

Tidak ada biaya penyusutan

Tidak menentukan gaji untuk pemilik

Banyaknya pesaing

Analisis pesaing

Strategi pesaing

Harga berpatokan harga

pesaing

Basis pelanggan

Kepercayaan pelanggan

Kekekcewaan pelanggan 
kenyamanan pelayanan, dan kegembiraan dan melakukannya dengan segera.

\begin{tabular}{|c|c|c|}
\hline $\begin{array}{l}\text { Hubungan } \\
\text { Dengan } \\
\text { Pemasok }\end{array}$ & $\begin{array}{l}\text { Pengusaha kecil tidak akan dipercaya oleh } \\
\text { pemasok bahan baku jika pembayaran } \\
\text { terhadap bahan baku tersebut sering } \\
\text { terlambat. (Suparyanto, 2012) }\end{array}$ & $\begin{array}{l}\text { Ketersediaan bahan baku } \\
\text { Kepercayaan pemasok }\end{array}$ \\
\hline $\begin{array}{l}\text { Transisi } \\
\text { Usaha }\end{array}$ & $\begin{array}{l}\text { Pertumbuhan mengharuskan wirausahawan } \\
\text { untuk mendelegasikan wewenang dan } \\
\text { melepaskan kegiatan pengendalian sehari-hari } \\
\text { hal yang tidak mampu dilakukan oleh banyak } \\
\text { wirausahawan. Zimmerer dan Scarborough } \\
(2008)\end{array}$ & $\begin{array}{l}\text { Pekerjaan didelegasikan } \\
\text { Mengalami perkembangan } \\
\text { usaha } \\
\text { Perubahan gaya manajemen }\end{array}$ \\
\hline Perekonomian & $\begin{array}{l}\text { Banyak alasan yang dikemukakan oleh para } \\
\text { usahawan pemula sehubungan dengan } \\
\text { kegagalan mereka, seperti terlalu banyaknya } \\
\text { pesaing, tingkat bunga bank yang tinggi, } \\
\text { perekonomian yang tidak menentu ................ } \\
\text { (Machfoedz, 2015) Bisnis keluarga } \\
\text { merupakan bagian integral dari perekonomian } \\
\text { (Zimmerer dan Scarborough, 2008). }\end{array}$ & $\begin{array}{l}\text { Kondisi perekonomian tidak } \\
\text { menentu } \\
\text { Hukum ekonomi, skala } \\
\text { produksi rendah maka harga } \\
\text { tinggi }\end{array}$ \\
\hline
\end{tabular}

Peneliti melakukan wawancara terhadap 12 orang narasumber. Diantaranya 7 orang lulusan kelas Ide Bisnis yang mengalami kegagalan dalam mendirikan usaha barunya, dan 5 orang lulusan kelas Ide Bisnis yang masih berwirausaha hingga saat ini (bulan Januari 2018).

Pada penelitian ini, teknik pengumpulan data menggunakan teknik gabungan/triangulasi, yaitu dengan melakukan observasi program WUB Jabar, mewawancara narasumber secara online (melalui chat Whatsapp), dan mengobservasi dokumentasi objek usaha.

Peneliti melakukan wawancara melalui media online dikarenakan keterbatasan jarak, yakni banyak narasumber berada di luar kota. Namun keabsahan narasumber sudah diuji dengan mencocokkan kartu identitas yang ditunjukkan narasumber dengan data narasumber yang tercantum pada database peserta WUB Jabar.

Setelah wawancara dilakukan, peneliti melakukan member check untuk memastikan kesimpulan yang telah peneliti buat adalah benar, sesuai dengan informasi yang ingin dijelaskan para narasumber. Tujuan member check adalah untuk mengetahui seberapa jauh data yang diperoleh sesuai dengan apa yang diberikan oleh pemberi data (Sugiyono, 2014)

Teknik analisis data menggunakan Model Miles dan Huberman dalam Sugiyono (2014). Model interaktif ini dilakukan secara terus menerus sampai tuntas, sehingga datanya sudah jenuh. Terdiri dari tiga hal utama yaitu reduksi data (data reduction), penyajian data (data display) dan penarikan kesimpulan atau verifikasi (conclution drawing/verification).

\section{HASIL PENELITIAN DAN PEMBAHASAN}

Sebagai gambaran awal tentang karakteristik narasumber dalam penelitian ini terangkum dalam tabel 3 berikut: 
Tabel 3. Karakteristik Narasumber

\begin{tabular}{|c|c|c|c|c|c|}
\hline No. & Nama Usaha & Bidang & $\begin{array}{l}\text { Bentuk } \\
\text { Usaha }\end{array}$ & Lokasi Usaha & Keterangan \\
\hline 1 & $\begin{array}{l}\text { Yomi Broker } \\
\text { (brownies } \\
\text { kering) }\end{array}$ & Makanan & $\begin{array}{l}\text { Usaha } \\
\text { Mikro }\end{array}$ & Kota Bandung & $\begin{array}{l}\text { Gagal. Tidak mencapai } 1 \\
\text { tahun }\end{array}$ \\
\hline 2 & Ayam Bakar & $\begin{array}{l}\text { Makanan- } \\
\text { minuman }\end{array}$ & Usaha Kecil & Kab. Bandung & $\begin{array}{l}\text { Gagal. Tidak mencapai } 1 \\
\text { tahun }\end{array}$ \\
\hline 3 & France Yoghurt & Minuman & $\begin{array}{l}\text { Usaha } \\
\text { Mikro }\end{array}$ & Kota Bandung & $\begin{array}{l}\text { Gagal. Tidak mencapai } 1 \\
\text { tahun }\end{array}$ \\
\hline 4 & Telur Asin HS & Makanan & $\begin{array}{l}\text { Usaha } \\
\text { Mikro }\end{array}$ & Kab. Cirebon & $\begin{array}{l}\text { Gagal. Tidak mencapai } 1 \\
\text { tahun }\end{array}$ \\
\hline 5 & $\begin{array}{l}\text { Kedai Susu } \\
\text { Murni }\end{array}$ & Minuman & $\begin{array}{l}\text { Usaha } \\
\text { Mikro }\end{array}$ & Kab.Majalengka & $\begin{array}{l}\text { Gagal. Tidak mencapai } 1 \\
\text { tahun }\end{array}$ \\
\hline 6 & $\begin{array}{l}\text { Rak (tas, sepatu, } \\
\text { kerudung) }\end{array}$ & Konveksi & $\begin{array}{l}\text { Usaha } \\
\text { Mikro }\end{array}$ & Kab. Bandung & $\begin{array}{l}\text { Gagal. Setelah mencapai } \\
1 \text { tahun }\end{array}$ \\
\hline 7 & Ceuyah & Makanan & $\begin{array}{l}\text { Usaha } \\
\text { Mikro }\end{array}$ & Kota Bandung & $\begin{array}{l}\text { Gagal. Setelah mencapai } \\
1 \text { tahun }\end{array}$ \\
\hline 8 & Entira Yoghurt & Minuman & $\begin{array}{l}\text { Usaha } \\
\text { Mikro }\end{array}$ & Kab.Sumedang & $\begin{array}{l}\text { Masih berlanjut. Belum } \\
\text { mencapai } 1 \text { tahun }\end{array}$ \\
\hline 9 & Biru Salon & Salon & Usaha Kecil & Kab. Garut & $\begin{array}{l}\text { Masih berlanjut. Sudah } \\
\text { mencapai } 1 \text { tahun }\end{array}$ \\
\hline 10 & $\begin{array}{l}\text { RC Fashion } \\
\text { Muslim } \\
\text { Indonesia }\end{array}$ & Konveksi & $\begin{array}{l}\text { Usaha } \\
\text { Mikro }\end{array}$ & Kab. Cianjur & $\begin{array}{l}\text { Masih berlanjut. Sudah } \\
\text { mencapai } 1 \text { tahun }\end{array}$ \\
\hline 11 & Dapur Boedjang & $\begin{array}{l}\text { Makanan- } \\
\text { minuman }\end{array}$ & $\begin{array}{l}\text { Usaha } \\
\text { Mikro }\end{array}$ & Kota Bandung & $\begin{array}{l}\text { Masih berlanjut. Sudah } \\
\text { mencapai } 1 \text { tahun }\end{array}$ \\
\hline 12 & $\begin{array}{l}\text { Brownies } \\
\text { Camer }\end{array}$ & Makanan & $\begin{array}{l}\text { Usaha } \\
\text { Mikro }\end{array}$ & Kab. Bogor & $\begin{array}{l}\text { Masih berlanjut. Sudah } \\
\text { mencapai } 1 \text { tahun }\end{array}$ \\
\hline
\end{tabular}

Berdasarkan data yang telah dihimpun dari hasil wawancara, menunjukkan bahwa para lulusan memiliki motivasi untuk berwirausaha yang cenderung besar, hanya 2 orang dari 12 nasarumber menyatakan keinginannya untuk berwirausaha sedang saja.

Dari 12 narasumber, 11 orang menyatakan belum memiliki cukup pengetahuan dan pengalaman saat mendirikan usaha barunya. Mayoritas narasumber menyatakan keinginannya untuk mengikuti program WUB Jabar adalah untuk menambah pengetahuan berwirausaha, untuk mengembangkan diri, dan karena ingin menjadi pengusaha.

Dalam perencanaan usaha, semua narasumber membuat proposal usaha namun tidak semua membuat Business Canvas Model (BMC) pasca mengikuti Program WUB Jabar. Empat narasumber menyatakan terkendala saat menyusun perencanaan usaha, 2 narasumber menyatakan penyusunan rencana usaha tidak ada kendala namun kendala terjadi saat pelaksanaannya. Dan semua narasumber melakukan analisis kelayakan usaha sebelum memulai usaha.

Mengenai kepemilikan usaha, 5 usaha berbentuk perusahaan peseorangan, 7 usaha berbentuk persekutuan. Persekutuan usaha diantaranya dilakukan dengan keluarga maupun dengan teman. Sebelas usaha belum berbadan hukum, namun 1 usaha yakni RC Fashion Muslim Indonesia sudah memiliki IUMK (Izin Usaha Mikro Kecil). Dua usaha termasuk kriteria usaha kecil, yakni usaha ayam bakar dan usaha Biru Salon, sedangkan 10 usaha lainnya termasuk kriteria usaha mikro. 
Sumber permodalan untuk memulai usaha diantaranya ada yang bersumber dari dana pribadi, pinjaman dari teman atau orang tua, maupun pinjaman dari bank berupa kredit.

Hasil wawancara mengenai pendampingan yang dilakukan penyelenggara Program WUB Jabar terhadap para lulusan, menunjukkan narasumber yang tidak mengalami kegagalan usaha lebih sering mendapatkan bimbingan, dibandingkan narasumber yang mengalami kegagalan usaha. Para narasumber menginginkan peningkatan untuk program ini, misalnya berupa pendampingan lanjutan, atau pelatihan yang lebih memperbanyak praktik dibanding teori.

\section{Penyebab Kegagalan Usaha Baru para Lulusan}

Berdasarkan hasil analisis, pembahasan mengenai penyebab kegagalan usaha baru para lulusan adalah sebagai berikut:

1. Motivasi para wirausahawan untuk berwirausaha cenderung besar. Namun, ada seorang narasumber yang menyatakan bahwa motivasinya untuk berwirausaha salah, karena ia memiliki komitmen ingin berwirausaha yang besar, namun tidak ditunjang dengan perencanaan usaha dan pelaksanaan usaha yang matang. Temuan ini tidak sejalan dengan asumsi yang dikemukakan ibu Siti Nur Maftuhah selaku koordinator pendamping yang menyatakan bahwa kegagalan usaha para lulusan disebabkan oleh motivasi usaha yang lemah.

2. Enam dari 7 narasumber menyatakan tidak memiliki pengalaman dan pengetahuan berwirausaha yang cukup. Sebanyak 4 dari 7 narasumber menyatakan kekurangan pengalaman menyebabkan kegagalan usahanya. Dan sebanyak 3 narasumber menyatakan kekurangan pengetahuan berwirausaha menebabkan kegagalan usahanya. Hal ini serupa dengan teori Machfoedz (2015) mengenai penyebab kegagalan usaha kecil yakni "Kurang pengalaman dan tidak memulai dengan mempelajari sesuatu tentang perusahaan". Temuan ini sejalan dengan asumsi yang dikemukakan ibu Siti Nur Maftuhah selaku koordinator pendamping yang menyatakan bahwa kegagalan usaha para lulusan disebabkan oleh pengetahuan yang terbatas.

3. Tiga narasumber menyatakan kendala pada perencanaan usaha menyebabkan kegagalan usaha. Seorang narasumber menyatakan tidak terpikirkan membuat rencana usaha karena usahanya hanya dilakukan oleh sendiri. Seorang narasumber menyatakan kedala dalam membuat rencana usaha karena harga yang selalu berubah. Dan seorang narasumber lainnya menyatakan perencanaan usahanya tidak matang, kendala dalam perencanaan usaha dikarenakan pengetahuan masih sedikit terkait pasar, pemasok, dan alur bisnis. Temuan ini pun sejalan dengan asumsi yang dikemukakan ibu Siti Nur Maftuhah selaku koordinator pendamping yang menyatakan bahwa kegagalan usaha para lulusan disebabkan oleh perencanaan usaha yang tidak matang.

4. Tiga dari 7 narasumber menyatakan kendala pada proses menganalisis kelayakan usaha menjadi penyebab kegagalan usaha. Seorang narasumber menyatakan kurang paham dalam menganalisi kelayakan usaha. Seorang narasumber menyatakan kendala dalam menganalisis kelayakan usaha 
karena kurangnya pengetahuan dan kurangnya relasi. Seorang nasarumber menyatakan kendala dalam menganalisis kelayakan usaha terletak pada menganalisis SWOT (kekuatan, kelemahan, peluang, ancaman usaha), menganalisis produk sejenis, dan menganalisis pesaing. Menurut Suryana (2008) "hasil studi kelayakan usaha pada prinsipnya bisa digunakan untuk 3 hal salah satunya yakni untuk merintis usaha baru”. Analisis kelayakan usaha penting dilakukan untuk dapat mengukur layak atau tidaknya suatu bisnis sebelum dilaksanakan.

5. Empat dari 7 narasumber menyatakan kendala pada kepemilikan usaha adalah penyebab kegagalan. Seorang nasarumber menyatakan, mengalami kendala dengan sekutu usahanya, dikarenakan pada saat membuat usaha tidak melakukan perjanjian tertulis. Temuan ini sejalan dengan teori Zimmerer dan Scarborough (2008) yakni "Para sekutu sering sekali mengira bahwa mereka tahu apa yang mereka sepakati, namun di kemudian hari didapati bahwa sebenarnya tidak terjadi kesepakatan”. Zimmerer juga menyatakan "kelemahan persekutuan diantaranya kewajiban tak terbatas pada setidaknya seorang sekutu, ... kesulitan untuk menyingkirkan kepentingan persekutuan tanpa membubarkan persekutuan, kurangnya kesinambungan, potensi konflik pribadi dan wewenang, ...”, hal ini adalah yang terjadi pada kasus kegagalan usaha Ceuyah.

6. Enam dari 7 narasumber menyatakan penyebab kegagalan usahanya dikarenakan kendala pada permodalan, diantaranya kendala pengajuan pinjaman modal ke bank, tidak adanya uang (modal), tidak berani mengajukan pinjaman modal, perencanaan kebutuhan modal yang tidak sesuai, dan modal yang dipakai untuk hal lain bersifat pribadi. Kendalakendala ini juga menyebabkan kendala pada aspek lainnya, misalkan kekurangan modal menyebabkan tidak dapat membayar karyawan, tidak dapat membeli bahan baku skala besar, tidak dapat memutarkan modal untuk penjualan, tidak dapat membeli alat produksi yang lebih canggih, atau tidak dapat membeli untuk alat produksi (mesin) tambahan. Temuan ini menunjukkan kesesuaian dengan asumsi yang dikemukakan para penyelenggara Program WUB Jabar, yakni ibu Hetty Susilawati dan asumsi ibu Siti Nur Maftuhah yang menyatakan bahwa penyebab kegagalan usaha baru para lulusan dikarenakan faktor permodalan. Juga banyak teori para ahli yang menyatakan faktor permodalan menjadi penyebab kegagalan usaha, diantaranya menurut Hisrich et. al. (2008) yang berpendapat "salah satu masalah tersulit dalam proses pendirian usaha baru adalah mendapatkan modal.”

7. Hanya 2 orang yang menyatakan kegagalan usaha disebabkan oleh faktor manajemen SDM. Seorang nasarumber menyatakan kegagalan usahanya dikarenakan tidak memiliki karyawan (usaha hanya dijalankan oleh sendiri). Seorang nasarumber menyatakan kegagalan usahanya karena karyawan tidak sesuai standar yang dibutuhkan (salah memilih karyawan).

8. Tiga dari 7 narasumber menyatakan kegagalan usaha dikarenakan kendala pada aspek manajemen operasi. Permasalahannya diantaranya tidak memiliki karyawan untuk membantu proses produksi, cuaca yang tidak mendukung, dan alat produksi yang digunakan tidak modern. 
9. Empat dari 7 narasumber menyatakan kegagalan usahanya dikarenakan masalah pada aspek pemasaran. Diantaranya dikarenakan sepi pembeli, maupun dikarenakan modal yang terbatas untuk menitipkan barang pada toko yang menjadi mitra usaha.

10. Lalu pada aspek manajemen keuangan, ada 2 narasumber yang menyatakan kegagalan usaha dikarenakan sering lupa mencatat keuangan usahanya.

11. Permasalahan-permasalahan pada aspek manajemen pemasaran, manajemen operasi, manajemen SDM, dan manajemen keuangan seperti yang terpapar pada poin 7 sampai 10, menunjukkan kesesuaian dengan teori Suparyanto yakni "Kelemahan yang paling pokok yang dialami oleh sebagian besar usaha kecil adalah pada aspek manajemen".

12. Hanya 2 dari 7 narasumber menyatakan usahanya gagal dikarenakan pesaing. Seorang nasarumber menilai pesaing lebih unggul dalam pasar dan jaringan yang lebih kuat.

13. Hanya 1 narasumber yang menyatakan kegagalan usahanya dikarenakan kendala dengan pelanggan. Seorang nasarumber menyatakan kegagalan usahanya dikarenakan pelanggan dari luar pulau yang tidak membayar hutang pembelian barang, hal ini adalah yang terjadi pada kasus kegagalan usaha Rak.

14. Hanya 2 dari 7 narasumber menyatakan usahanya gagal dikarenakan kendala pada pemasok, lebih tepatnya yaitu harga bahan baku yang ditetapkan pemasok yang tidak sesuai atau cenderung mahal menyebabkan harga jual menjadi tinggi. Sehingga produk sulit terjual, karena kelemahan daya beli konsumen.

15. Hanya 1 dari 7 narasumber menyatakan kegagalan usahanya dikarenakan transisi usaha, yakni saat omset menurun drastis.

16. Dua dari 7 narasumber menyatakan usahanya gagal dikarenakan faktor perekonomian, yakni rendahnya daya beli masyarakat.

17. Faktor lain yang menjadi penyebab kegagalan usaha para lulusan diantaranya faktor kesibukan lain, faktor kesehatan lulusan, faktor cuaca buruk, dan perizinan usaha. Proses perizinan usaha yang membutuhkan waktu sangat lama menyebabkan kesulitan untuk memasarkan produk. Hal ini dialami oleh usaha Ceuyah, untuk mendapatkan nomor P-IRT dan label halal produk makanannya membutuhkan waktu lebih dari 1 tahun. Kendala cuaca buruk dialami usaha France Yoghurt, yaitu kesulitan mengakses lokasi pemasok yang terkena banjir.

\section{Kendala Paling Sulit Diatasi dalam Mendirikan Usaha Baru para Lulusan}

Berdasarkan hasil analisis, pembahasan mengenai kendala yang paling sulit diatasi para lulusan yang tidak mengalami kegagalan usaha adalah sebagai berikut:

1. Kesulitan menganalisis kelayakan usaha dari aspek modal, lokasi usaha, dan kelayakan produk yang harus terlebih dahulu mendapat kepercayaan calon konsumen. Pemilik usaha Biru Salon menyatakan kesulitan mendapatkan lokasi yang layak. Hal ini menurut Zimmerer dan Scarborough adalah dapat menjadi salah satu penyebab kegagalan usaha, seperti dalam kutipan berikut "lokasi perusahaan sering kali dipilih tanpa 
penelitian, pengamatan, dan perencanaan yang layak. Beberapa pemilik bisnis baru memilih lokasi hanya karena ada tempat kosong. Akan tetapi, masalah lokasi terlalu riskan untuk dilakukan secara untung-untungan" (Zimmerer dan Scarborough , 2008). Pemilik usaha Biru Salon sampai saat ini masih menganalisis dan mencari lokasi yang layak untuk bisnisnya.

2. Tiga dari 5 narasumber menyatakan bahwa kendala yang paling sulit diatasi adalah faktor permodalan. Namun perbedaan kendala pada faktor permodalan yang dialami para lulusan yang tidak mengalami kegagalan usaha ini berbeda dengan kendala permodalan pada para lulusan yang mengalami kegagalan usaha. Jika para lulusan yang mengalami kegagalan menyatakan kendala permodalan adalah untuk memulai mendirikan usaha, para lulusan yang tidak mengalami kegagalan menyatakan kendala permodalan adalah untuk pengembangan usaha.

3. Pada usaha RC Fashion Muslim Indonesia, kendala manajemen SDM juga menjadi salah satu kendala yang paling sulit diatasi, karena kekurangan karyawan yang kompeten. Dari 5 narasumber, hanya pemilik RC Fashion Muslim Indonesia yang menyatakan kendala paling sulit adalah pada aspek manajemen SDM.

4. Terdapat 2 narasumber yang menyatakan kendala pada manajemen produksi menjadi kendala paling sulit. Pada usaha Entira Yoghurt, kendala produksi ini adalah ketiadaan mobil khusus untuk distribusi yogurt, hal ini disebabkan kekurangan modal. Sedangkan pada usaha Brownis Camer, kendala produksi disebabkan faktor cuaca yang buruk, bahan baku kacang harus dikeringkan di bawah sinar matahari langsung, apabila cuaca mendung proses ini akan terhambat.

5. Terdapat 1 narasumber menyatakan kendala paling sulit salah satunya adalah pada aspek keuangan, dikarenakan sering terjadi selisih pencatatan keuangan.

6. Terdapat 1 narasumber menyatakan kendala paling sulit salah satunya adalah persaingan usaha, banyaknya pesaing usaha sejenis Biru Salon.

7. Terdapat 1 narasumber menyatakan kendala paling sulit salah satunya adalah karena tidak memiliki pelanggan, seperti yang dialami usaha Brownis Camer.

8. Terdapat 2 narasumber menyatakan kendala paling sulit salah satunya pada aspek transisi usaha, yakni saat ramai atau sepi pembeli. Dan juga dikarenakan ketidakadaan bahan baku dan kurir.

9. Lalu ditemukan kendala lain yakni perizinan usaha yang lama mempengaruhi kesulitan pemasaran. Seperti yang dialami usaha Entira Yoghurt untuk memperoleh Merek Dagang dan nomor BPOM harus menunggu selama 2 tahun.

\section{Cara Para Lulusan Mengatasi Kendala dalam Mendirikan Usaha Baru}

Kendala yang dialami para lulusan berbeda-beda, cara mengatasi kendala-kendala ini pun berbeda-beda. Misalkan pada kendala permodalan, ada lulusan yang memilih mengajukan pinjaman modal ke bank, dan ada yang tidak mengajukan. Pada umumnya para lulusan mengumpulkan modal dari uang pribadi, teman ataupun orang tua. Perbedaan cara menangani kendala mendirikan usaha baru pun tidak dapat dibedakan antara lulusan yang 
mengalami kegagalan dan yang tidak, tapi lebih kepada individu masingmasing. Lebih kepada prinsip setiap lulusan berwirausaha. Salah satu contohnya yaitu pemilik usaha RC Fashion Muslim Indonesia yang tidak mau mengajukan pinjaman modal ke bank dikarenakan hal tersebut riba, hal ini menunjukkan prinsip yang Ia anut sebagai seorang muslim.

Para lulusan yang tidak mengalami kegagalan beranggapan bahwa penurunan performa usaha adalah hal yang wajar, sehingga mereka tidak bermaksud untuk berhenti berwirausaha sekalipun performa usahanya sedang menurun. Mereka beranggapan bahwa suatu permasalahan pasti bisa dihadapi.

Hal ini bukan menjadi asumsi bahwa para lulusan yang mengalami kegagalan beranggapan sebaliknya. Lulusan yang mengalami kegagalan pun sudah berupaya mengatasi masalah-masalah pada usaha mereka, namun tetap tidak mendapat titik temunya. Sehingga menutup usaha menjadi jalan keluar dari permasalahan itu.

Semua lulusan yang mengalami kegagalan dalam mendirikan usaha baru pasca mengikuti pelatihan WUB Jabar menyatakan tetap akan berwirausaha, baik akan merintis kembali usaha yang telah gagal, atau beralih merintis usaha yang baru.

\section{SIMPULAN}

Berdasarkan hasil penelitian dan pembahasan yang disusun sesuai perumusan masalah, dapat ditarik kesimpulan sebagai berikut: 1) Setiap kasus kegagalan mendirikan usaha baru yang dialami para lulusan Program WUB Jabar Kelas Ide Bisnis itu unik. Dari 7 studi kasus kegagalan usaha baru yang telah diteliti, tidak ada kesamaan mutlak mengenai kendala yang menjadi penyebabnya. Kendala pada permodalan menjadi penyebab kegagalan tertinggi, sebanyak 6 narasumber menyatakan hal tersebut. Kendala pada permodalan juga menjadi penyebab kendala-kendala pada faktor lainnya. Penemuan ini membuktikan asumsi dari para penyelenggara program WUB Jabar benar, bahwa kendala pada permodalan adalah penyebab utama kegagalan usaha baru para lulusan. Ditemukan faktor penyebab kegagalan lainnya, yakni: (a) Perizinan usaha yang lama mempengaruhi kesulitan pemasaran; (b) Kondisi kesehatan wirausahawan yang kurang baik (sakit) menyebabkan kesulitan dalam mengelola usaha; (c) Cuaca yang buruk menghambat proses produksi. (2) Kendala yang paling sulit diatasi oleh usaha baru yang tidak mengalami kegagalan diantaranya: (a) Kendala dalam menganalisis kelayakan usaha; (b) Kendala pada permodalan menjadi hal yang paling sulit untuk diatasi, terkait modal yang dibutuhkan adalah untuk pengembangan usaha; (c) Kendala yang paling sulit pada aspek manajemen operasi terkait ketidaktersediaan alat yang dibutuhkan; (d) Kendala lainnya yang dianggap menjadi hal paling sulit adalah persaingan, pencatatan keuangan yang tidak benar, ketiadaan pelanggan, transisi usaha saat pembeli sedikit, perizinan usaha yang lama. (3) Perbedaan cara para narasumber menangani kendala pada usahanya tidak dapat dibedakan antara lulusan yang mengalami kegagalan dan yang tidak. Cara tiap lulusan menangani kendala lebih tergantung prinsip yang dipegang oleh masing-masing lulusan. 
Berdasarkan hasil wawancara terhadap para narasumber mengenai saran mereka untuk program WUB Jabar, peneliti membuat rekomendasi untuk perubahan program Wirausaha Baru Jawa Barat yakni: (1) Pendampingan dilakukan lebih intensif, untuk selalu memberikan arahan kepada usaha baru para lulusan agar bisa mengatasi kendala-kendala, dan agar tidak mengalami kegagalan usaha. (2) Pelatihan dilakukan diseluruh kabupaten dan kota di Provinsi Jawa Barat untuk meningkatkan jumlah peserta, jangan hanya dilakukan di kota Bandung. (3) Lebih memperbanyak pelatihan praktik untuk meningkatkan keterampilan berwirausaha dibandingkan dengan teori berwirausaha. (4) Program WUB Jabar harus memilih para pendamping dari praktisi-praktisi ahli di bidang usaha yang beragam jenis. Misalkan untuk peserta yang ingin mendirikan usaha brownis, pertemukanlah dengan pendamping yang ahli pada usaha brownis. (5) Menciptakan program dana bergulir, untuk mengatasi kendala permodalan.

\section{DAFTAR RUJUKAN}

Alma, B. 2014. Pengantar Bisnis. Bandung: Alfabeta

Astamoen, Moko P. 2008. Entrepreneurship dalam Perspektif Kondisi Bangsa Indonesia. Bandung: Alfabera.

Hisrich, Robert D., Peters, Michael P., Shepherd Dean A. 2008. Entrepreneurship: Kewirausahaan. Edisi 7. Jakarta: Salemba Empat.

Machfoedz, Mas'ud. 2015. Kewirausahaan Metode, Manajemen, dan Implementasi. Yogyakarta, Indonesia : BPFE

Sugiyono. 2014. Memahami Penelitian Kualitatif. Bandung: Alfabeta.

Suparyanto, R.W.. 2012. Kewirausahaan Konsep dan Realita pada Usaha Kecil. Bandung: Alfabeta.

Suparyanto, R.W. \& Bari, Abdul. 2014. Pengantar Bisnis: Konsep dan Realita pada Usaha Kecil (Cetakan ke-1). Tangerang: Pustaka Mandiri.

Suryana. 2008. Kewirausahaan Pedoman Praktis: Kiat dan Proses Menuju Sukses. Edisi 3 (Cetakan keempat). Jakarta, Indonesia : Salemba Empat.

Suryana. 2014. Kewirausahaan: Kiat dan Proses Menuju Sukses. Edisi 4. Jakarta, Indonesia : Salemba Empat.

Undang-undang No.20 tahun 2008 tentang UMKM.

Zimmerer, T. W., \& Scarborough, N. M. 2008. Kewirausahaan dan Manajemen Usaha Kecil, Edisi 5, Buku 1. Jakarta: Salemba Empat. 